\title{
"Transição de cor": Raça e abolição nas estampas de negros de Angelo Agostini na Revista Illustrada
}

\author{
Marcelo Balaban*
}

\section{RESUMO}

Angelo Agostini ficou conhecido como um dos principais caricaturistas do Brasil oitocentista. Sua fama se deveu, em grande medida, às imagens que publicou protagonizadas por personagens negros. Nelas, o artista italiano teria sido incansável defensor da causa dos escravos. Neste artigo, busco analisar essas imagens por meio de outras chaves interpretativas. No lugar de festejar o implacável abolicionista, procuro desvendar os sentidos raciais e as lógicas políticas que informavam seus desenhos de negros. Em cada um deles, o ítalo-brasileiro Agostini produz, e reproduz, estereótipos sobre os sujeitos tematizados, definindo seus personagens negros ora como vadios, ora como perigosos e irracionais, ou, ainda, como passivos diante dos horrores da instituição servil. Misturando raça e escravidão na criação desses desenhos, Agostini produz, nesse processo, a própria imagem como um dos heróis da grande causa.

Palavras-chave: Angelo Agostini; abolição; raça; Revista Illustrada; imprensa ilustrada.

\section{ABSTRACT}

Angelo Agostini is widely known as one of the most important cartoonists of nineteencentury Brazil. His fame was built on the many images of Blacks he published. In those images, the Italian artist seems to be a tireless defender of the slaves' cause. This article analyzes such images through a different set of interpretive keys. Instead of celebrating the implacable abolitionist, it seeks the underlying racial meanings, and the political logic of his caricatures of Black people. The Italian-Brazilian artist created, and recreated stereotypes of his subjects, defining those characters as sluggards, or as dangerous and irrational, and even as passive under the horrors of slavery. Mixing slavery and race to produce his drawings, Agostini created his own reputation as an abolitionist hero.

Keywords: Angelo Agostini, abolition, race, Revista Illustrada, illustrated press. 
“TransiçÃo de cor”: RaÇa E aboliçÃo nas estampas de negros de Angelo Agostini na Revista IlluUstrada

\section{Marcelo Balaban}

\section{Um herói da abolição?}

A grande fase, a fase áurea da carreira artística de Angelo Agostini, foi na Revista Illustrada, um periódico lançado no Rio de Janeiro com o objetivo de agitar, pela crítica livre e sem reservas, as questóes mais importantes da vida dos habitantes da cidade, e levantar pelas causas da República e da abolição, principalmente, uma campanha pertinaz e profícua.

A sua ação como abolicionista é um traço inconfundível de sua vida; ela exprime bem eloquentemente a nobreza dos seus sentimentos e a sinceridade com que os sabia afirmar, mesmo contra todas as conveniências de ordem pessoal. ${ }^{1}$

Angelo Agostini faleceu no dia 23 de janeiro de 1910. Poucos dias após sua morte, a revista Careta publicou uma fotografia mostrando o carro fúnebre que levou o caixão, cercado por coroas de flores, para o cemitério São João Batista. No canto superior direito da imagem, em montagem bem característica dos hebdomadários da época, o semanário inseriu o busto do velho artista do lápis vestindo um terno escuro, contrastando com a barba e o cabelo brancos. ${ }^{2}$ As homenagens recebidas, além de enfatizar seu talento como desenhista, ressaltaram o empenho que devotara às principais causas políticas e sociais do tempo. Especial destaque foi dado, como fez o cronista anônimo d'O Paiz, para a abolição da escravidão.

A ênfase dada pelos elogios fúnebres, posteriormente repetida por outras narrativas biográficas sobre o autor, ${ }^{3}$ ao empenho abolicionista de Angelo Agostini foi as estampas por ele feitas e publicadas, sobretudo na Revista Illustrada, sobre a escravidão. Nelas é possível encontrar denúncias aos horrores da instituição servil, ao desumano tratamento dos cativos, bem como aos efeitos deletérios da escravidão para a nação brasileira. Mesmo não deixando de ressaltar o talento artístico de Agostini, por alguns considerado o pai da caricatura brasileira, os epitáfios fizeram com que ele tenha sido sobretudo lembrado como um operário da grande causa, um herói da abolição. Afinal, ele teria sido um homem sem vaidades pessoais que devorara a vida, sem medir esforços, para redimir uma raça oprimida e desfigurada pela terrível instituição servil.

Essa forma de lembrar e dar sentido à vida e obra de Agostini, entre outras consequências, fez com que seus desenhos sobre a escravidão tenham sido estudados de forma unívoca, e sempre laudatória. Além de enaltecer as qualidades do autor, serviam para corroborar, e engrossar, a versão de ter sido o sucesso da abolição obra de apenas um seleto grupo de apaixonados homens que, a partir da década de 1880, devotaram a vida para a causa dos

\footnotetext{
1 "Angelo Agostini". O Paiz, 24 jan. 1910, p. 3.

2 "Angelo Agostini". Careta, n. 87, p. 29, 29 jan. 1910.

${ }^{3}$ Estou me referindo a pequenos textos biográficos que foram publicados na imprensa e em trabalhos sobre a caricatura no Brasil. Bom exemplo pode ser encontrado no clássico, e ainda fundamental, História da Caricatura no Brasil, de Herman Lima.
} 
“TransiçÃo de cor”: RaÇa E aboliçÃo nas estampas de negros de Angelo Agostini na Revista IlluUstrada

\section{Marcelo Balaban}

escravos, argumento que ganhou foros de verdade histórica por meio do trabalho de alguns historiadores. ${ }^{4}$ Seguindo as trilhas abertas por trabalhos recentes sobre a escravidão, a abolição e a imprensa ilustrada no Brasil oitocentista, ${ }^{5}$ este artigo propóe uma abordagem diferente das imagens de negros publicadas na Revista Illustrada. Em vez de enaltecer e dar sentido único à vida e à obra de Agostini, busco desvendar significados políticos e sociais dos desenhos. Quando submetidos a sistemático questionamento, é possível observar como constroem imagens do escravo e da escravidão e qual o significado dessas construçóes. Longe de serem transparência da realidade, tais estampas eram pontos de vista com sentidos políticos precisos. Sentidos recheados de conflitos que, quando devidamente inquiridos, direcionam uma releitura capaz de pôr em evidência novas abordagens sobre parte do movimento abolicionista, da imprensa ilustrada do Rio de Janeiro da década de 1880 e até mesmo dos personagens negros que protagonizavam cenas impressionantes naqueles tumultuados anos que precederam a abolição da escravidão no Brasil.

\footnotetext{
${ }^{4}$ A historiografia sobre o processo da abolição no Brasil é vasta, além de já bastante longeva. Na década de 1970 e 1980 importantes estudos, como os de CONRAD, Joseph. Os últimos anos da escravatura no Brasil1850-1888. Rio de Janeiro: Civilização Brasileira, 1975 e COSTA, Emilia Viotti da. A Abolição. Sáo Paulo: Editora Unesp, 2008 [primeira edição de 1987], ainda incorporaram em seus argumentos boa parte da retórica de uma parcela do movimento abolicionista. Com as profundas reviravoltas sofridas pela historiografia da escravidão, que desde a década de 1980 vem incorporando o ponto de vista dos cativos na história da escravidão, os trabalhos sobre a abolição e o abolicionismo sofreram da mesma forma intensas transformaçôes. Conferir, entre outros: MACHADO, Maria Helena Pereira Toledo. O plano e o pânico: os movimentos sociais na década da abolição. São Paulo: Editora da UFRJ/Edusp, 1994; AZEVEDO, Celia Maria Marinho de. Onda negra, medo branco: o negro no imaginário das elites — século XIX. 3. ed. São Paulo: Annablume, 2004; AZEVEDO, Elciene. O direito dos escravos: lutas jurídicas e abolicionismo na província de São Paulo. Campinas: Editora da Unicamp, 2010 e ROCHA, Antonio Penalves. Abolicionistas brasileiros e ingleses: a coligação entre Joaquim Nabuco e a British and Foreing Anti-Slavery Society (1880-1902). São Paulo: Editora Unesp/Santana do Parnaíba; São Paulo: BBS Treinamento e Consultoria em Finanças, 2009.

${ }^{5} \mathrm{O}$ interesse pela imprensa ilustrada vem crescendo e muitos e interessantes trabalhos estáo aparecendo. Ver, entre outros: LUSTOSA, Isabel (Org.). Imprensa, humor e caricatura: a questão dos estereótipos. Belo Horizonte: Editora da UFMG, 2011; KNAUSS, Paulo; MALTA, Marize; OLIVEIRA, Cláudia de; VELOSO, Mônica Pimenta (Orgs.). Revistas ilustradas: modos de ler e ver no segundo reinado. Rio de Janeiro: Mauad, 2011; KERR, David S. Caricature and French political culture, 1830-1848: Charles Philipon and the illustrated press. Oxford: Clarendon Press; Nova York: Oxford University Press, 2000; MARTIN, Michèle. Images at war: Illustrated Periodicals and Constructed Nations. Toronto: University of Toronto Press, 2006; BALABAN, Marcelo. Poeta do lápis: sátira e política na trajetória de Angelo Agostini no Brasil imperial. Campinas: Editora da Unicamp, 2009; MARINGONI, Gilbeto. Angelo Agostini - A imprensa ilustrada da corte à capital federal, 1864-1910. 1. ed. São Paulo: Devir Livraria, 2011 e LUSTOSA, Isabel (Org.). Agostini. Obra, paixão e arte do italiano que desenhou o Brasil (1843-1910). Rio de Janeiro: Casa de Ruy Barbosa, coleção FCRB Estudos, v. 15, 2014. Os estudos sobre escravidão e pós-abolição no Brasil são incontáveis. Cito apenas alguns que influenciaram mais diretamente este artigo: CHALHOUB, Sidney. A força da escravidão: ilegalidade e costume no Brasil oitocentista. Sáo Paulo: Companhia das Letras, 2012; SLENES, Robert W. Na senzala, uma flor: esperanças e recordaçóes na formação da família escrava. Campinas: Editora da Unicamp, 2011; MATTOS, Hebe Maria. Das cores do silêncio — significados da liberdade no sudoeste escravista. Brasil. Século XIX. Rio de Janeiro: Nova Fronteira, 1998 e ALBUQUERQUE, Wlamyra R. de. O jogo da dissimulaçâo: abolição e cidadania negra no Brasil. São Paulo: Companhia das Letras, 2009.
} 


\section{Números imprecisos}

As imagens de negros - escravos, livres ou libertos — feitas por Angelo Agostini são difíceis de interpretar. Na imprensa ilustrada oitocentista, de modo geral, o número de desenhos de negros não era muito grande. Essa realidade se alterou na década de 1880, quando ocorre um significativo crescimento de tais estampas. Mesmo assim, elas são minoria na Revista Illustrada. A quantidade de desenhos de personagens negros - escravos, libertos e livres - em outras folhas ilustradas do período, no entanto, é ainda menor. ${ }^{6}$ Talvez por isso Joaquim Nabuco tenha definido o semanário do colega ítalo-brasileiro como "[...] a Bíblia abolicionista do povo, o qual não sabe ler". ' Em razão do grande analfabetismo que grassava na populaçáo brasileira, as imagens teriam um poder especial, o de levar a propaganda abolicionista à população, ajudando a converter o povo à religiáo da liberdade. Todo esse elogio, no entanto, pouco ajuda na decifração dos sentidos e das questóes embutidas nas imagens. Muito mais do que monumento abolicionista, elas, se devidamente questionadas, revelam conflitos e debates travados no decorrer da década de 1880 sobre o processo de extinçáo do elemento servil e a participação nele de personagens negros — reais e ficcionais. Oferecem um amplo conjunto de questóes ligadas às noçôes de raça, concepçóes de escravidão e do escravo, e sobre como essas noçôes foram mobilizadas por alguns abolicionistas. Constituem ainda um vigoroso indício das incertezas, e os dilemas a elas associados, que marcaram o processo da abolição no Brasil. ${ }^{8}$

Um primeiro caminho para acessar esse universo é a via quantitativa. Contar as imagens de negros publicadas nas páginas do hebdomadário de Agostini é exercício difícil, mas compensador. À medida que a contagem é feita, é possível verificar que os números produzidos respondem a uma lógica classificatória muito particular. Chama a atenção, num primeiro olhar, que os personagens negros são muito genéricos. Raros são os desenhos em que podemos detalhar características do personagem com algum grau de certeza. Via de regra, apenas observando o desenho, não é fácil identificar a condição dos personagens, especialmente para libertos e livres. Quanto aos escravos, em geral aparecerem descalços, usam roupas brancas e simples, mas por vezes podemos nos enganar, ou sermos enganados pela fonte. No que toca à naturalidade, as estampas são ainda mais escorregadias, sendo impossível definir ou diferenciar crioulos de africanos, e vice-versa. Mesmo a cor, ou seja, se o personagem seria definido na época como um pardo, mulato, cabra ou negro, é elemento impreciso. No que

\footnotetext{
${ }^{6}$ Estou me referindo às mais importantes folhas da época, tais como O Mequetrefe, O Besouro, O Figaro, entre outros.

${ }^{7}$ NABUCO, Joaquim, “Angelo Agostini”. O Paiz, 30 ago. 1888, p. 1.

${ }^{8}$ Parte da bibliografia sobre o movimento abolicionista e sobre o fim da escravidão no Brasil trabalha com a noção teleológica de que a causa da abolição estava vencida na década de 1880. As imagens aqui analisadas, assim como outras fontes, mostram que o destino da escravidão era incerto, marcado por um conjunto de dúvidas que definia o processo.
} 
tange a todos esses aspectos, a única referência segura está na legenda, mas estas nem sempre esclarecem nossas dúvidas.

Apesar de tantos problemas, foi possível encontrar trinta imagens de negros, aquelas onde esses personagens são o centro do desenho, além de 160 com negros, ou seja, aquelas em que eles integram a estampa, dividindo a cena com outros personagens. Temos, portanto, 190 estampas de um universo de pouco mais de 1.600 desenhos, produzidas ao longo de 13 anos, entre os anos de 1876 e 1888. Se o número não é muito grande, ele não chega a ser desprezível, perfazendo pouco mais de $10 \%$ do total das estampas publicadas no período. Esses números, como dito, são muito pouco precisos e bastante incertos. Referem-se a um conjunto dessemelhante de estampas, que se distribuem no tempo de modo distinto. Em 1879, há 14 imagens com negros, em 1881, encontra-se 21 imagens com negros e uma de negro e, em 1888, foram publicadas quatro imagens de negros e 18 com negros. Além de revelar um crescimento de imagens com ou sobre negros, os dados não permitem, sozinhos, maiores voos interpretativos. No entanto, quando confrontados com análises qualitativas, ficam mais interessantes.

Antes de prosseguir, uma breve explicação: porque chamar de "imagens de negros" as estampas abolicionistas de Angelo Agostini? A intenção com essa denominação, um tanto arbitrária, como a maioria das escolhas metodológicas que somos obrigados a fazer, é destacar que as caricaturas tinham um parti pris fundamental: elas operavam com arraigadas, e nem sempre fáceis de interpretar, noçôes de raça, tão próprias de uma sociedade criada e organizada pela escravidão africana. A cor constituía, então, um aspecto central dos desenhos. Nesse sentido, tal classificação parte da premissa de que as relaçôes sociais no Brasil oitocentista estavam profundamente marcadas por diferentes concepçôes ligadas a cor ou definidas por ela. Os diferentes sentidos da cor fazem dela uma categoria social. Marcus Rediker, no seu estudo sobre o tráfico transatlântico de africanos, argumenta que, ao "produzir trabalhadores para as plantaçôes, o navio-fábrica também produziu 'raça'". 'Mesmo não se referindo à experiência brasileira, tampouco ao século XIX, creio ser possível utilizar sua ideia. A racialização das relaçôes sociais seria uma das consequências dessa profunda e traumática experiência humana. A análise de desenhos abolicionistas de Angelo Agostini produzidos na década de 1880 permite flagrar alguns desses sentidos.

\section{Preferência pelo mulato}

Em 1878, após dez anos de hegemonia conservadora, a política imperial passou por mais uma de suas conhecidas reviravoltas. O partido conservador foi substituído no poder por

\footnotetext{
${ }^{9}$ REDIKER, Marcus. Introdução. In: O navio negreiro: uma história humana. São Paulo: Companhia das Letras, 2011, p. 18.
} 
“Transiçấo de cor”: Raça e aboliçấo nas estampas de negros de Angelo Agostini na Revista Illustrada

\section{Marcelo Balaban}

um gabinete liberal, sob a direção do experiente Visconde de Sinimbu. Um dos principais pepinos que o novo Presidente do Conselho de Ministros deveria descascar dizia respeito à agricultura. Para enfrentar essa demanda, Sinimbu convocou, em novembro daquele ano, um Congresso Agrícola, iniciativa até então inédita. O objetivo principal era ouvir, sem intermediários, a lavoura, como eram chamados os grandes agricultores. O congresso reuniu, nos cálculos de José Murilo de Carvalho, cerca de 400 delegados do Sul e do Sudeste. ${ }^{10} \mathrm{O}$ encontro agitou o Município Neutro, produziu debates na imprensa diária e, como não poderia deixar de ser, ganhou as sempre divertidas páginas dos semanários ilustrados.

Figura 1: Revista Illustrada, n. 120, p. 4-5, 13 jul. 1878

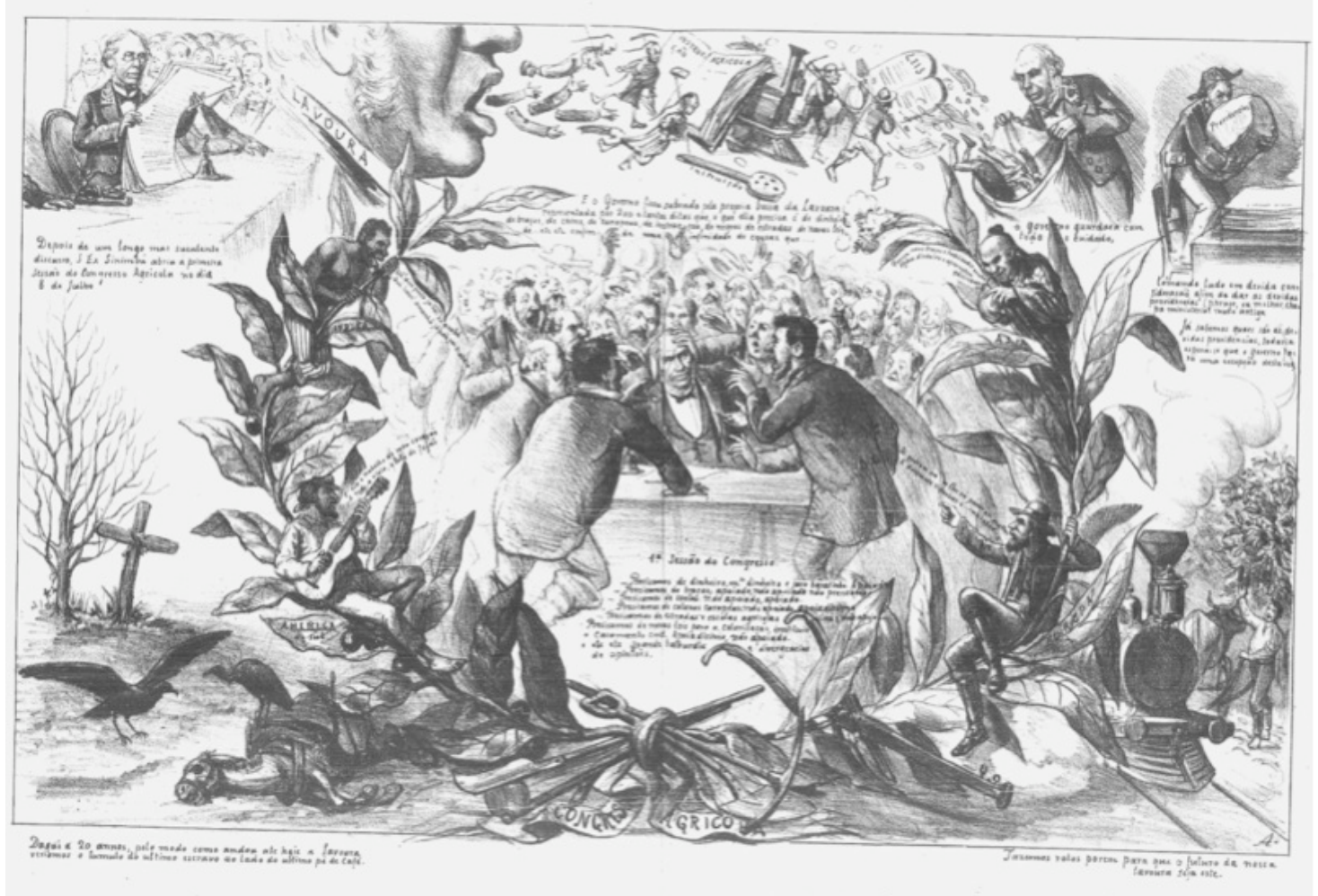

Imagens como esta são difíceis de interpretar. Combinam um resumo dos acontecimentos com a construção de sentidos a respeito deles. ${ }^{11}$ Nesta espécie de crônica ilustrada, publicada nas duas páginas centrais do jornal, misturam-se comentários satíricos ao congresso

\footnotetext{
${ }^{10}$ Foram convidados representantes das províncias do Rio de Janeiro, Minas Gerais, São Paulo, Município Neutro e Espírito Santo.

${ }^{11}$ CARVALHO, José Murilo de. Introdução. In: . Congresso Agrícola - edição fac-similar dos anais do Congresso Agrícola, realizado no Rio de Janeiro em 1878. Rio de Janeiro: Fundação Casa de Rui Barbosa, 1988, p. vi.
} 
com avaliaçóes a respeito do problema da mão de obra, do financiamento da lavoura e seu futuro. Há muitos modos de ler a estampa. Em cada um deles, um novo e inusitado sentido emerge. Por várias razôes, estamos diante de um verdadeiro enigma histórico.

Um primeiro caminho de leitura é oferecido pela legenda. Nela encontramos uma descrição comentada do congresso propriamente dito. Após o "longo, mas suculento" discurso de abertura de Sinimbu, que aparece no canto superior esquerdo, são detalhadas algumas demandas da Lavoura, representada por uma grande boca, de onde saem braços, leis, trens, chineses, trabalhadores, uma palmatória, tudo caindo diretamente no saco do governo. $\mathrm{O}$ único consenso entre os delegados seria a necessidade de " $\mathrm{m}^{\text {to }}$ dinheiro e juro baratinho". As demais solicitaçôes são controversas, motivo de discussão e da confusão reinante.

A imagem não estava longe da realidade, muito embora seja uma versão propositalmente exagerada. Os anais do Congresso Agrícola trazem um questionário, formulado pelo governo e distribuído aos delegados, que tinha a intençâo de descobrir as necessidades mais urgentes da lavoura. Com apenas quatro perguntas, procurava saber, primeiramente, quais as mais urgentes necessidades da grande lavoura; em seguida, nas três outras questôes, trata diretamente da mão de obra. Buscar descobrir se havia carência de "braços para manter"12 a agricultura, pede sugestóes sobre o modo de suprir a eventual falta e, finalmente, pergunta se os "ingênuos, filhos de escravas", aqueles que nasceram após a vigência da lei de 28 de setembro de 1871, poderiam constituir "um elemento de trabalho livre". Toda sorte de proposta foi oferecida em resposta. Como sintetiza a imagem, houve uma "grande balburdia e divergências de opiniáo", com destaque para os temores advindos dos efeitos da lei de 28 de setembro. Esse temor ajuda a explicar por que as perguntas II, III e sobretudo a IV tratavam do problema da máo de obra. Explica também uma proposta de promoção da imigraçáo de chineses:

Art. 1ํㅡㄹ Que a primeira necessidade da lavoura é a aquisição de trabalhadores livres mediante salários módicos, e de trabalhadores que se habituem ao nosso clima, e ao sistema de cultura extensiva, que em geral e por muitos anos será quase a única do Brasil; para cujo fim de modo algum se poderá contar por enquanto com os europeus, devendo-se antes preferir, como um meio de transição entre o trabalho servil e o de todo livre, a aquisição de trabalhadores de outros povos de raça ou civilização inferior à nossa própria. [grifo do autor] ${ }^{13}$

O trecho integra a resposta do representante da província de São Paulo, J. C. de M. Monteiro Barros. ${ }^{14}$ Chama a atenção seu forte conteúdo racial. Para promover uma "tran-

\footnotetext{
${ }^{12}$ Idem.

${ }^{13}$ Idem.

${ }^{14}$ A proposta possui quatro artigos com 22 parágrafos e define critérios rigorosos para os contratos dos imigrantes, com regras para pagamento das despesas com o transporte, um meio de educar os ingênuos, filhos de escravas, pelo Estado, até a idade de 21 anos, e mais uma série de pontos para garantir braços aptos e baratos para a lavoura.
} 
sição" do trabalho escravo para o de todo livre, sugere a "aquisiçấo de trabalhadores" que fossem, a um tempo, "inferiores" e capazes de adaptação fácil ao "nosso clima" e à "cultura extensiva". No seu modo arraigadamente racializado de entender as coisas, o devotado representante da província de São Paulo se referia a africanos, coolies e chins. Proposta como um tipo de solução transitória, não era intenção fixar definitivamente esses trabalhadores no Brasil, somente preparar o terreno para os novos tempos. Afinal, tratava-se de pessoas de civilização e raça inferiores.

A questão racial ocupa lugar destacado na estampa porque aparecia nos debates do congresso. Não se trata de opção fortuita de Agostini. Ela é evidenciada por meio de quatro personagens, que constituem versóes de tipos de trabalhadores, distintos pelo lugar de origem, cultura e raça: o africano, o sul-americano, o asiático e o europeu. Todos sáo reclamados pela lavoura, segundo deixa evidente a legenda. Por isso cada um é colocado sobre uma folha dos dois frondosos pés de café que ao mesmo tempo serve de moldura ao tumulto produzido pelos agricultores e de ponto de observação dos trabalhadores. Esses personagens, então, participam da cena. E o fazem de um lugar privilegiado. De modo estranho, eles parecem estar em vantagem em relaçáo aos senhores de terra e de gente, como fica bem marcado na fala de cada um deles. Por isso é preciso destacar o lugar em que cada trabalhador é disposto no desenho. Este, aparentemente, não é aleatório. Mas tal disposição não define uma só forma de leitura. As opçóes de leitura ficam, ao que tudo leva a crer, abertas, permitindo cruzamentos e sentidos diversos.

"Daqui a 20 anos, pelo modo como andou até hoje a Lavoura, veríamos o túmulo do último escravo ao lado do último pé de café", diz a parte da legenda localizada no canto inferior esquerdo da imagem. A previsão é bastante pessimista e a "Lavoura", que por vir grafada com a primeira letra maiúscula significa os poderosos senhores de terras e de gente, seria o principal responsável pelo infeliz desfecho. Do outro lado, a legenda traz votos de um futuro promissor para a "lavoura", agora com a primeira letra minúscula, fazendo referência à agricultura, a base econômica da nação. Essa pode ser uma forma de ler o desenho, imaginando uma diferença quanto aos lados. No esquerdo, poder-se-ia então fazer uma relação entre os dois personagens associados ao não trabalho, à vadiagem, com a morte da lavoura. Do lado esquerdo, há os dois personagens associados ao trabalho, por isso estariam ao lado do futuro próspero desejado para a agricultura. É possível ainda ler a imagem reunindo os personagens que estão no alto do ramo de café e os que estão embaixo. Nesse caso, os de cima, considerados a raça inferior pelo representante da província de São Paulo, observam a confusão de um lugar ainda mais privilegiado, estando, por isso, em situação de tirar mais proveito do caos que observavam. Os que estão embaixo, ambos de barba, estariam em situação menos vantajosa. Ainda assim, apresentam suas demandas, expressam estar cientes das vantagens que a confusão reinante no centro do desenho poderia lhes proporcionar. São estas formas de leitura possíveis, mas não devem ser tomadas como definitivas. 
Para complicar ainda mais a cena, podemos selecionar cada trabalhador individualmente e analisar suas falas. Cada personagem apresenta interesse particular, não convergindo nenhum deles com o da nação. $\mathrm{O}$ africano, falando um português incorreto, descalço, sem camisa, com a cor da pele ressaltada, a carapinha e o nariz largo, expressa seu entendimento da liberdade: seria para ele o fim do trabalho. O sul-americano, possivelmente representando o homem livre pobre no Brasil, com chapéu, roupas simples e viola na mão, se interessa apenas pelo descanso, a viola e o "tutu de feijão". Do outro lado, o chinês, com seu longo rabo de cavalo, nariz fino e olhos puxados, demonstra astúcia ao negociar sua força de trabalho em troca de dinheiro e galinhas. Finalmente, o europeu, mais bem-vestido, também apresenta suas condiçôes para "povoar as matas" brasileiras: riquezas e mulatas. Os quatro trabalhadores náo eram, em síntese, dignos de confiança. $\mathrm{O}$ africano e o sul-americano seriam vadios. $\mathrm{O}$ chinês era ganancioso. $\mathrm{O}$ branco europeu, ainda mais ganancioso - náo quer apenas dinheiro, mas riquezas —, apresenta um problema adicional: o desejo por "mulatas".

A referência ao interesse do europeu por mulatas é preciosa. Indica uma preocupação com o contato de imigrantes europeus com parcela expressiva da população brasileira. Nesse sentido, o modelo de trabalhador branco europeu náo seria bom para o Brasil, como salientou J. C. de M. Monteiro Barros na passagem já citada. O desejo manifestado pelo personagem por mulatas fazia dele tão indesejado como aqueles de "raças inferiores". Para tentar desvendar o sentido dessa relação, o conhecido romance de Aloizio Azevedo $O$ cortiço fornece pistas preciosas. O português Jerônimo é um trabalhador dedicado e pai de família exemplar. Tudo muda, no entanto, quanto entra em cena Rita Baiana. A mestiça sensual, cujo meneios eram "cheios de uma graça irresistível, simples, primitiva, feita toda de pecado, toda de paraíso, com muito de serpente e muito de mulher", ${ }^{15}$ não tarda a seduzir o português. $\mathrm{O}$ contato com a mulata transforma o personagem em um perigoso e indesejado vadio, muito semelhante a Firmo, o mulato capoeira que fora amásio de Rita Baiana antes de Jerônimo. Desta feita, a simples presença de negros e mulatos seria entendida por parte da lavoura, por alguns dos leitores da Revista e quem sabe também por seus redatores e desenhistas, como um problema para a constituição de um mercado de trabalho livre no Brasil. O tipo ideal de trabalhador livre para o Brasil, seguindo essa lógica, não existiria. Diante desse aparentemente insolúvel dilema, a continuidade do trabalho compulsório seria a única solução possível. Mas não é esse um argumento da estampa. Se ela permite essa leitura, certamente não foi feita para defender tal argumento. A cena é perturbadora porque está organizada tanto por uma nada velada crítica ao governo e à lavoura, como aos tipos de trabalhadores que nela figuram. A constituição de um mercado de trabalho livre no Brasil emergia como tema delicado, aparentemente sem solução. Angelo Agostini, autor desse quadro aterrador, não oferece um argumento marcadamente abolicionista. Nessa imagem

\footnotetext{
${ }^{15}$ AZEVEDO, Aloisio. O cortiço. Rio de Janeiro: Garnier, 1890, p. 108. Disponível em: <http://www.brasiliana.usp.br/bbd/handle/1918/00227900\#page/9/mode/lup>. Acesso em: 9 jan. 2015.
} 
complexa e nada conclusiva, constrói uma interpretação caótica do Congresso Agrícola, colocando em evidência alguns dos problemas a serem enfrentados no que dizia respeito a oferta de mão de obra para a lavoura.

Se parece haver distinçôes grandes sobre qual seria o melhor tipo de trabalhador, não resta dúvida que a estampa opera com a ideia de que era preciso consenso e organização dos que estão no centro da cena para lidar com o problema da mão de obra. Uma percepção de que a escravidáo não duraria para sempre faz parte do sentido dessa crônica imagética. As figuras do negro vadio, do sul-americano preguiçoso, do chinês avarento e do europeu ganancioso e seduzido pelos encantos da mulata são preciosas. Possivelmente compartilhadas por muitos leitores, apontam para a centralidade das percepçôes raciais no debate público no império, ao mesmo tempo que aprofundam o problema associado à forte presença de africanos e seus descendentes no país. Descobrir um caminho seguro para extinguir de uma vez a escravidão no Brasil era encontrar uma solução para o dilema racial. Uma vez que tanto o personagem chinês como o europeu não eram ainda parte integrante da realidade brasileira, é possível alinhavar o argumento, nada explícito, de que a imagem combatia soluçóes imigrantistas, entendidas como potencialmente perigosas.

O desenho, ao que tudo leva a crer de modo proposital, não é conclusivo. Não organiza uma narrativa com um sentido inequívoco e único. Lança elementos, partes da controvérsia sobre imigração, escravidão, leis, ferrovias, uma infinidade de temas ordenados de modo aberto, com vistas a permitir diferentes interpretaçôes. Não se pode esquecer, no entanto, que operava com sentidos que circulavam na sociedade. Muitos leitores eram bem informados a respeito dos debates sobre o problema da mão de obra ou as discussóes do Congresso Agrícola e tinham lá suas opinióes a respeito da escravidão e o destino da lavoura. Por essa razáo, a separação da cena entre agricultores e trabalhadores constitui o elemento central do desenho e aponta para os perigos de deixar que aqueles personagens, mesmo os de raça e civilização "superiores", percebessem a confusão reinante. Se a classe senhorial não se entendia, o risco era o país ficar à mercê dos trabalhadores. Misturando um presente conturbado com uma previsáo nada alvissareira de futuro, o desenho mostra como os arraigados conceitos e preconceitos raciais organizavam a visáo do abolicionista Agostini. Se ele defenderia cada vez mais a causa dos cativos, nem por isso os veria como aliados, ou como sujeitos ordeiros, trabalhadores e confiáveis. Eles seriam, antes de tudo, perigosos.

No mesmo número da Revista, um dos aspectos apresentados na crônica central volta a ser explorado. 
Figura 2: Revista Illustrada, n. 120, p. 8, 13 jul. 1878

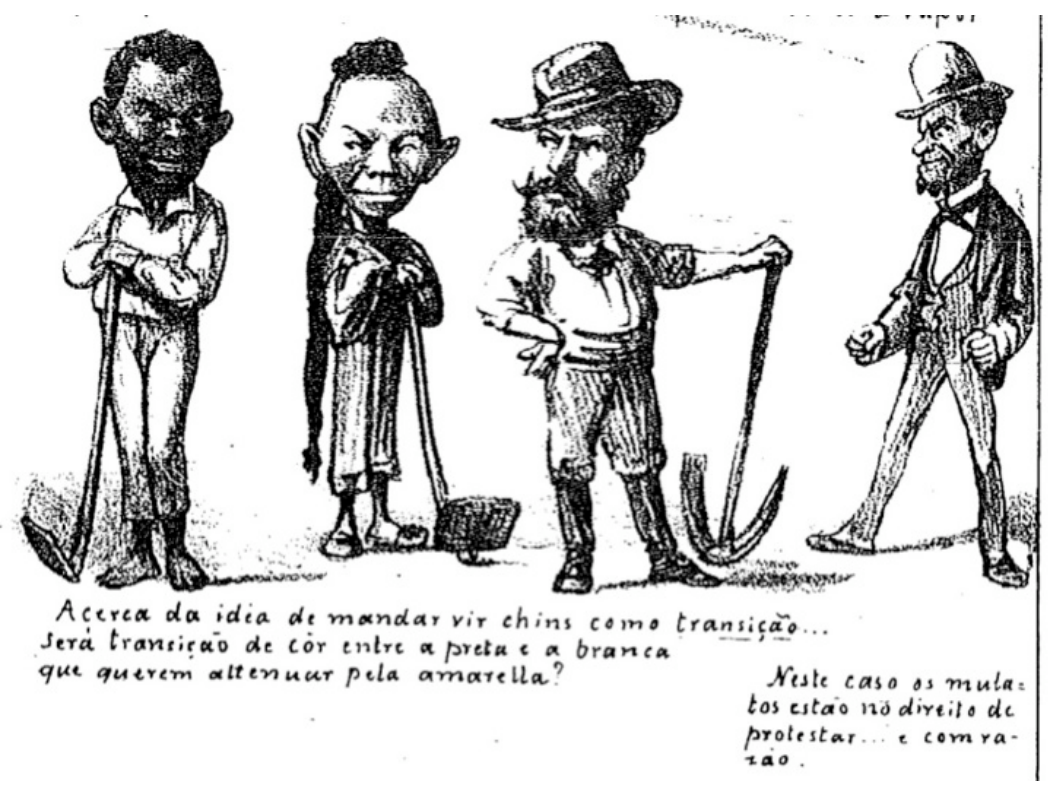

Neste detalhe do desenho maior que ocupa toda a última página da edição, a cor dos trabalhadores volta ao centro da cena. A palavra transição dá o tom da piada. No lugar de ser a transição do trabalho escravo para o livre, é "transição de cor entre a preta e a branca que querem atenuar pela amarela”. Isso provocaria o justo protesto do mulato, novamente figurando com o elemento provocador de dissenso. Ressalte-se que é dada "razáo" ao descontentamento do mulato, residindo aí tanto a graça como o sentido crítico da pilhéria. O desenho brinca com um gradiente de cores, apresentando motivos sociorraciais para ideia de "transição". Em outras palavras, define mais uma vez a raça como um elemento central do processo. Eis entáo que temos uma dúvida a respeito do sentido da piada: por que o mulato, deslocado na cena, bem-vestido, iria protestar? Mais ainda, contra o que ele protestaria?

A cena é montada de forma a sugerir uma peculiar "evolução da espécie", um progressivo melhoramento racial que parte do negro, deveria ter o mulato como o segundo elemento dessa cadeia evolutiva que levaria ao branco. Parece uma versão caricaturada de indigestos debates científicos a respeito do branqueamento ${ }^{16}$ já em voga na época. Se a leitura faz algum sentido, então o mulato iria protestar por ser alijado do processo "natural" rumo ao melhoramento. Não estou sugerindo com isso que este personagem rezasse pela cartilha científica que vislumbrava um futuro branco para a nação. Se alguns poderiam participar do debate, não há indícios de que ele fosse socialmente disseminado, nem que a estampa sugerisse isso. Apenas

\footnotetext{
${ }^{16}$ Sobre o debate científico sobre raça e nação no final do século XIX no Brasil ver, entre outros: SCHWARCZ, Lilia Moritz. O espetáculo das raças: cientistas, instituições e questão racial no Brasil — 1870-1930. São Paulo: Companhia das Letras, 1993, SKIDMORE, Thomas E. Preto no branco - raça e nacionalidade no pensamento brasileiro. São Paulo, Companhia das Letras: 2012 e CORREA, Mariza. As ilusóes da liberdade: a Escola Nina Rodrigues e a antropologia no Brasil. 2. ed. rev. Bragança Paulista: Edusf, 2001.
} 
estou argumentando no sentido de que mulatos poderiam, em algum grau, identificar-se com o mundo dos brancos. Isso explicaria a indignação do personagem, algo reforçado por sua aparência; bem alinhado, está com roupas de branco. $\mathrm{O}$ desenho, assim, por essa via indireta de análise, daria acesso a modos de agir de mulatos, negros, pardos, enfim, do que estou chamando de personagens negros. Esses sujeitos, por questôes diferentes das imaginadas por Agostini, poderiam se incomodar com a imigração de chineses e ao menos parte deles poderiam se sentir mais próximos dos brancos do que de negros escravos. A sua própria condição de liberdade concorreria para essa percepção. Obviamente, não é possível generalizar esse tipo de leitura, mas ela pode ser uma possibilidade, sobretudo se imaginarmos que desenhos como este não eram fruto apenas da imaginação do seu autor. Ele nasce também da presença e da ação dos sujeitos caricaturados. Mesmo sendo uma visão branca do mulato - neste caso de um estrangeiro - , quero sugerir que é possível alcançar o modo de ver de personagens como estes por meio do lápis de Agostini, assim como de outros olhares brancos. ${ }^{17}$

Mas o mulato não é o único incomodado com a situação. A cena mostra quatro cores bem destacadas, o preto, o amarelo, o branco e o mulato. Todos se entreolham desconfiados, numa atitude que sugere oposiçáo e disputa. De modo direto, os ódios raciais definem o sentido da cena, sáo o tema do desenho. Ele apresenta um outro aspecto, e uma crítica, à proposta de importaçáo de africanos, colliers, "chins" e europeus. No lugar de ser o caminho para o embranquecimento do país, a imigração provocaria ou aumentaria ódios raciais latentes, sendo a figura do mulato mais uma vez o elemento desagregador.

O debate sobre tensôes e ódios raciais no Brasil foi tema amplamente debatido por abolicionistas de diferentes orientaçôes. Joaquim Nabuco tinha opinião definida sobre o tema:

Quanto ao Brasil, meu próprio país e meu lar, só posso repetir aqui o que já lhe disse: mesmo com a escravidáo, nós não diferenciamos as pessoas pela cor. Há homens negros na vanguarda em todas as carreiras: nenhuma lhes é fechada seja por lei ou por antipatia pública ou pressão social. Alguns dos talentos mais brilhantes, em todos os tipos de superioridade intelectual, vêm da população negra. [grifo do autor ${ }^{18}$

Para Nabuco, o Brasil seria um tipo de "paraíso racial". A escravidão, dentre seus muitos efeitos deletérios, não teria produzido conflitos raciais. Seria precipitado, e mesmo um tanto ingênuo, dar crédito às palavras de Nabuco (embora muitos o tenham feito). Afinal, é difícil imaginar, e acreditar, que um país secularmente organizado pela escravidáo africana estaria livre de tensôes raciais. Seu argumento, no entanto, não é despropositado. Em primeiro lugar, é importante sublinhar ser a carta destinada a um abolicionista britânico. Nabuco buscava

\footnotetext{
${ }^{17}$ A inspiração para essa análise vem do belo livro de SLENES, Robert W. Na senzala, uma flor — esperanças e recordações na formação da família escrava — Brasil Sudoeste, século XIX, op. cit.

${ }^{18}$ BETHELL, Leslie; CARVALHO, José Murilo de (Orgs.). Joaquim Nabuco e os abolicionistas britânicos: Correspondência 1880-1905. Rio de Janeiro: Topbooks, 2008, p. 179.
} 
convencer o colega de causa que o país poderia acabar com a escravidão sem provocar uma revolução social. Trata-se, pois, de argumento político destinado a um interlocutor que, possivelmente, nunca pisara em terras brasileiras. Em outra carta, complementa seu argumento:

Além disso, após a queda do governo Sinimbu, que se tinha comprometido a fornecer cules aos agricultores de apenas duas províncias do sul já não há motivos para temer que os negros sejam substituídos pelo escravo amarelo e a herança do trabalho escravo pertencerá inteiramente às pessoas livres. ${ }^{19}$ [grifo do autor]

O nó do problema era exatamente aquele tematizado nas imagens analisadas. Para Nabuco, o posto de trabalho dos escravos deveria pertencer, após a abolição, aos libertos, que poderiam ser ensinados a viver como trabalhadores livres. $\mathrm{O}$ abolicionista lida, nesse caso, com a ideia de uma inferioridade social, fruto da violência da escravidão, e racial, pois defendia a tese de que os libertos deveriam ser educados para a liberdade. Caso não fossem aproveitados, então haveria um risco potencial de perturbaçáo da ordem e da paz social. Em suma, na lógica de Nabuco, para que a abolição fosse feita, era preciso, diria mesmo imprescindível, aproveitar a força de trabalho dos ex-escravos, pois somente dessa forma seriam evitadas tensóes e ódios raciais. Tal avaliação, portanto, se assemelha a uma das possíveis leituras da imagem de Agostini sobre o conturbado congresso agrícola. Em ambas as fontes, fim da escravidão e dilemas raciais caminham juntos.

$\mathrm{O}$ mesmo parece acontecer com o detalhe da Figura 2. No que dizia respeito à imigração de chins, ela seria potencialmente explosiva, pois poderia estimular ódios raciais. $\mathrm{O}$ chinês, no lugar do mulato, seria um elemento perturbador, um empecilho para o desenvolvimento de condiçóes necessárias para a abolição. $\mathrm{Na}$ estampa, ele aparece substituindo o mulato, que de imediato, e com razão, demonstraria sua insatisfação. Isso também se aplicava ao imigrante europeu, cujo olhar desconfiado sobre os colegas de raça inferior seria mais um foco de conflitos potenciais. Ao mesmo tempo que seria atraído, e seduzido, pela mulata, nutriria desconfianças e possíveis desavenças com os mulatos.

Esse argumento ganha força se levarmos em consideração os conceitos raciais que sustentavam muitas das posiçóes políticas relativas aos temas em pauta. Era justamente a diferença entre as raças que levaria a uma situação potencialmente perigosa. $\mathrm{O}$ ideal apresentado na imagem era inequívoco: o trabalho livre se confunde com o trabalho branco. Isso aparece nas duas imagens até aqui trabalhadas. No entanto, a realidade do país era outra. Era preciso lidar com a presença, ainda que incômoda, dos não brancos. Se a existência de uma raça inferior, um dos muitos legados da escravidão, já constituía um problema delicado, tanto mais complicada ficaria a situação com a introdução de outras raças, tanto a outra inferior — os chins — como a superior — os europeus. Além de tirar o lugar dos mulatos, iria produzir

\footnotetext{
${ }^{19}$ Ibidem, p. 57.
} 
ou arraigar ódios raciais. E a política ensinava, na opiniáo do conselheiro de Estado Pimenta Bueno, "a regra de não fala-se nisso" [das diferenças de cor e raça]. ${ }^{20}$

Muito bem, se é palatável o argumento de que Agostini, por meio de sua Revista, batia de frente com a proposta de imigração chinesa e europeia por motivos raciais, este não é o único elemento de reflexão que a imagem oferece. Observando com atenção, um detalhe desperta interesse e curiosidade: as roupas. O mulato, além de ser excluído do processo de transição para o trabalho livre, está bem-trajado, vestido de maneira bem diferente do estereótipo usual para os não brancos. Ele, da mesma forma, não carrega ferramenta de trabalho. Haveria, então, alguma relação entre a exclusão e essa roupa? O que não é difícil de imaginar, em primeiro lugar, é que a roupa serve para compor a pilhéria. Trata-se de uma piada difícil de entender, mas náo resta dúvida de que estamos diante de um gracejo oitocentista. Se era possível encontrar na época mulatos bem-sucedidos desfilando elegante indumentária pelas ruas da Corte, essa não era a regra, tampouco o caso do personagem dessa caricatura. Por um lado, o personagem não está vestido como um escravo, indicando uma possível condição de liberdade. Finalmente, aquela roupa náo lhe cai bem, não parece natural nele. A liberdade para um mulato, na construção da revista, não significava a entrada imediata no mundo urbano dos brancos, como poderia sugerir sua elegante roupa. Muito ao contrário, a graça é construída justamente em colocar roupas de branco num mulato. $\mathrm{O}$ contraste fica mais evidente com o descontentamento que o personagem demonstra em relação à imigração chinesa. O lugar "natural" dele seria o ocupado pelo chinês. No entanto, as roupas que iria vestir nesse lugar de transição se assemelhariam às do escravo. Por isso aquela roupa elegante soa estranha. Naquele terno, o mulato está fora de lugar, parecendo até mesmo um tanto ridículo. $\mathrm{O}$ mulato não tinha, ou não era desejável que tivesse, espaço no mundo civilizado dos brancos, razão pela qual deveria permanecer como uma espécie de caminho natural para o branqueamento da população: deveria ser ele, não o chinês, o elemento da "transiçáo" entre a cor "preta e a branca", ou da escravidáo para a liberdade. A existência do mulato seria, no modo de ver da Revista, a razão primeira e última para contestar qualquer proposta imigrantista, fosse ela voltada para a importação de indivíduos de raças inferiores ou superiores.

\section{"Cúmulo da amolação"}

Analisar os desenhos de negros de Angelo Agostini publicados na Revista Illustrada requer observar uma série de aspectos. Alguns mais evidentes, muitos bastante específicos, difíceis de serem identificados. As características raciais, as roupas, o lugar social, os traços fisionômi-

\footnotetext{
${ }^{20}$ CHALHOUB, Sidney. Solidariedade e liberdade: sociedades beneficentes de negros e negras no Rio de Janeiro na segunda metade do século XIX. In: CUNHA, Olívia Maria Gomes da; GOMES, Flávio dos Santos (Orgs.) Quase cidadão: histórias e antropologias da pós-emancipação no Brasil. Rio de Janeiro: FGV Editora, 2007, p. 219-239.
} 
cos, o motivo da estampa, o número do semanário em que aparecem constituem alguns dos elementos a serem observados com atençáo. Sáo aspectos cuidadosamente manejados pelos desenhistas. É razoável imaginar, sendo este um dos argumentos centrais deste texto, que esses retratos de negros, desenhos feitos com as intençôes variadas, produziam argumentos políticos.

Não se pode deixar de observar que os leitores da Revista Illustrada estavam acostumados às cotidianas cenas da escravidáo e poderiam ter clara dimensão do quâo artificiais eram esses personagens. Afinal, um dos elementos que organizavam os semanários caricatos era exatamente seu caráter aberto, quase sempre ambíguo, aliado a uma liberdade autoatribuída por esse tipo de folha. O humor lhes garantiria direitos especiais para falar do que bem quisessem da forma que entendessem. ${ }^{21}$ Isso faz dessa uma fonte particularmente delicada e escorregadia. Em muitas das imagens, misturam-se personagens reais com ficcionais, cenas verdadeiras com inventadas. Em outras, os sentidos são produzidos através de sutis matizes. De qualquer modo, eram organizadas pela sátira, um caminho sempre fértil para abordar temas delicados, uma vez que possuíam uma espécie de habeas corpus preventivo: o humor teria a capacidade de dissolver potenciais tensôes. Afinal, tratava-se de caricaturas, e elas podiam não ser levadas a sério.

O caso das reiteradas cenas de capoeiras, tidos e havidos como um perigo real a ser combatido, constitui neste conjunto um lugar de análise privilegiado.

Figura 3: Revista Illustrada, n. 174, p. 4, ago. 1879

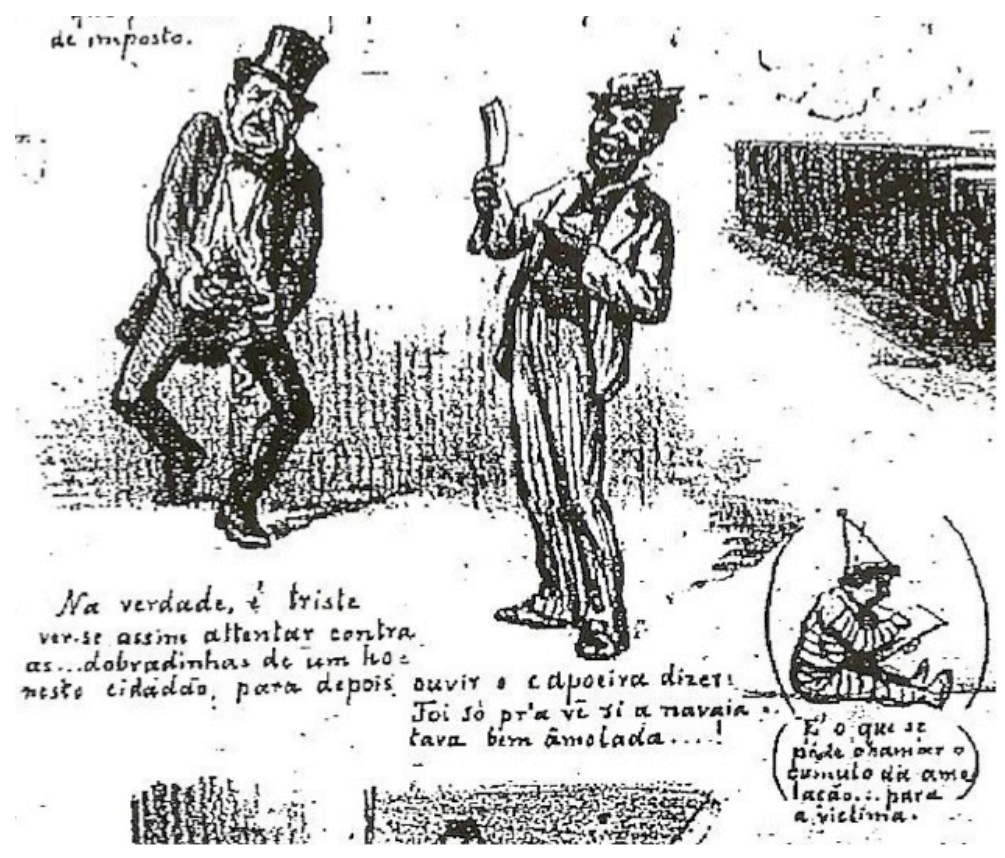

\footnotetext{
${ }^{21}$ Uma leitura cuidadosa dos antigos programas de folhas ilustradas publicadas na Corte leva a essa conclusão. Com suas diferenças, todas falam do humor associado a liberdade, tendo esta última característica especial para esse tipo de jornal.
} 
Neste detalhe, um sorridente capoeira acabara de investir "contra as... dobradinhas de um honesto cidadáo" simplesmente para testar o fio de sua navalha. Um misto de humor e horror organiza a cena. A legenda e o modo como o desenho é feito brincam com um assunto perigoso, com a intenção de alimentar o medo contra aqueles que faziam uso da navalha como arma. ${ }^{22} \mathrm{~A}$ brincadeira, produzida por meio de um exagero, tem um sentido de denúncia bem explícito: os perigosos valentôes náo estavam sendo devidamente reprimidos e combatidos pela polícia, tanto assim era que em outro quadro da mesma crônica visual figuram "praças de polícia" vestidos "à paisana" e jogando capoeira.

O pressuposto que permite a pilhéria, e a crítica nela contida, demanda acompanhamento mais cuidadoso. O personagem negro está bem composto. Não é possível afirmar que está bem-vestido, como sua vítima, ou o mulato da estampa analisada anteriormente. Este usa uma calça riscada, sapatos, camisa, paletó branco e chapéu. Via de regra, com variaçôes em pequenos detalhes, este é um modelo de roupa que identifica os capoeiras na Revista. É uma espécie de marca, um elemento que permitia fácil e imediata identificação. E não se trata de pura ficção, como pode ser observado nos livros de entrada e saída de prisioneiros da Casa de Detenção do Rio de Janeiro. Um dos motivos para recolher pessoas de cor era a capoeira. Esse motivo aparecia com algumas variaçóes: capoeira e uso de arma, capoeira e desordem, capoeira e ofensas físicas, e desordem, ou simplesmente capoeira. Ser identificado por este termo já era razáo suficiente para tornar a pessoa passível de ser recolhida ao xadrez, ainda que a capoeira em si, ou a capoeiragem, não configurasse crime no império.

Os livros que registram a entrada e a saída da Casa de Detenção do Rio de Janeiro, da década de 1860 até os anos de 1880, registram 169 casos associados à capoeiragem, de um total de 8.446 registros. O número não é grande, nem estatisticamente significativo, mas as informaçôes de cada ficha são valiosas. Do total de prisóes, 19 referem-se às pessoas identificadas como brancas, mais de $10 \%$, portanto, distribuídos entre portugueses e brasileiros. $\mathrm{O}$ restante aparece como pretos, pardos, fulos e morenos. Sáo considerados escravos 84 deles, e 82, livres. Todos homens. Por detrás desse termo, que carrega um grau de subjetividade que torna difícil identificar com precisão o crime cometido, definindo um tipo de suspeição sobre determinados sujeitos, e não um delito propriamente dito, escondia-se muita diversidade. As imagens náo davam conta de toda essa variedade, carregando nas tintas na construção de um personagem perigoso por natureza, um tipo a ser temido e combatido, capaz de cometer uma grande atrocidade, como abrir com a navalha a barriga de um transeunte por motivo fútil. Operavam e alimentavam a suspeição que de certo modo definia o grupo. Nesse sentido, é curioso observar como um autor identificado por seu empenho em favor dos escravos produz conteúdo tão fortemente marcado por uma visão racializada; neste caso

\footnotetext{
${ }^{22}$ A imprensa diária, vez por outra, dava notícia de façanhas envolvendo capoeiras. A sessão "Cronica Policial" da Gazeta de Noticias de 7 de julho de 1887 conta a história do capoeira conhecido como Fuáo Satyro de tal, que, ao ser conduzido para a estação policial por fazer "grande salceiro", conseguiu, "veloz, lépido e ligeiro", desvencilhar-se dos praças, indo "o nosso pintalegrete" se refugiar na taverna no 57 .
} 
diria, sem rebuço, ser diretamente racista. A forma sempre ambígua que dava o tom do conteúdo publicado na Revista, uma opção de Angelo Agostini, torna sempre arriscado associar diretamente qualquer conteúdo à opiniáo do autor. No caso desta estampa, no entanto, era a cor que dava sentido ao personagem e explicava seu ato.

E a barriga? Afinal, por que o ataque era direcionado à barriga? Encontrei muitas outras imagens e referências em textos literários de ataques de capoeiras à barriga de personagens brancos e descritos como burgueses. No lugar de índice, ou prova da maldade inata desse tipo de personagem - os capoeiras reais e os ficcionais - a escolha por esse alvo em particular pode ser explicada de outra forma. Poderia ser o ataque a um símbolo de distinção social, à arrogância de brancos bem-fornidos, com panças grandes e cheias. $\mathrm{O}$ alvo, nessa perspectiva, seria a evidência de tensóes sociorraciais e modos de agir dos capoeiras transformados em prova de incivilidade pelo lápis, táo afiando como a navalha do capoeira, de Agostini e outros autores. Nesse sentido, os ataques às barrigas seriam uma forma de os capoeiras conquistarem respeito social por meio da produção do medo. Eles deveriam ser temidos, porque andavam armados e poderiam, sem prévio aviso, rasgar o abdômen de um transeunte qualquer. Assim, desenhos como esse podem dar acesso, a um tempo, ao ponto de vista dos autores e dos personagens, claro que estes últimos de forma mais indireta.

Outro aspecto a ser observado é a roupa. Os livros de registro de entrada e saída da Casa de Detenção são ricos em detalhes neste quesito; as roupas são listadas e descritas em seus menores detalhes, o que nem sempre é informaçáo fácil de obter. $\mathrm{O}$ trabalhador que deu entrada como Pedro Crioulo no dia 8/9/1879, permanecendo preso por dois dias, usava "calça de cor e camisa de chita". O cozinheiro Cantidio Pardo, que deu entrada em 9/9/1879, trajava "calça de brim, camisa branca, paletó e colete pretos e chapéu de lebre". Todos os dois eram escravos. O servente pardo Benigno José da Silva, livre, vestia "camisa de riscado e calça branca" quando foi preso em 24/10/1861. Para finalizar, o escravo Francisco Crioulo, servente, detido em 18/05/1863, vestindo "camisa branca, calça riscada, paletó de brim, chapéu de lebre". ${ }^{23}$ Por esses poucos casos, é fácil observar que não há um padrão, um tipo de roupa que identificasse os capoeiras. A roupa do personagem do desenho muito se assemelha à de Francisco Crioulo, o que torna o desenho verossímil, mas não necessariamente verdadeiro.

As vestes desse tipo de personagem negro da Revista tinham a função de identificar e caracterizar um tipo. Não é possível, nos desenhos, descobrir a condição, se escravo, livre ou liberto, outra generalização significativa. As roupas, sendo sempre as mesmas, criam um padrão situado entre a aparência de personagens brancos bem-vestidos e aqueles que podiam, nas páginas do semanário, ser facilmente identificados como escravos. Além de extremamente violentos, e um tanto bestiais, teriam relaçóes com a polícia e a política, sendo

\footnotetext{
${ }^{23}$ Informaçôes retiradas do "Banco Casa de Detenção do Rio de Janeiro”, Cecult, Unicamp.
} 
“Transiçẫo de cor": RaÇa e aboliçấo nas estampas de negros de Angelo Agostini na Revista Illustrada

responsáveis por cuidar das eleiçôes. ${ }^{24}$ Isso lhes garantiria algum dinheiro, além de proteção, um dos reiterados motivos de crítica do periódico de Angelo Agostini. A crítica, no entanto, volta-se para as autoridades públicas. Os capoeiras, por sua parte, são apresentados, sem necessidade de maiores justificativas, como perigos reais e potenciais, elementos perturbadores da tranquilidade pública, que deveriam ser sistematicamente vigiados e combatidos, por não serem confiáveis. Não são, desta feita, entendidos como sujeitos políticos. Eram, segundo o lápis de Angelo Agostini, pessoas perigosas, difíceis de controlar e combater. Representavam uma constante ameaça à ordem pública, devendo por isso ser alvo permanente de vigilância e repressão. Parte central, e subjacente, do perigo que simbolizavam era definido pela bestialidade inerente à raça negra, uma premissa dos desenhos do abolicionista Agostini. A defesa cada dia mais intensa que o desenhista e proprietário da Revista Illustrada fará no decorrer da década de 1880 em prol da abolição da escravidáo estava baseada nesse pressuposto racial.

Se os temíveis capoeiras eram um tipo de personagem negro que figurava nas páginas da Revista Illustrada, eles não eram os únicos.

Figura 4 - Revista Illustrada, n. 427, 18 fev. 1886

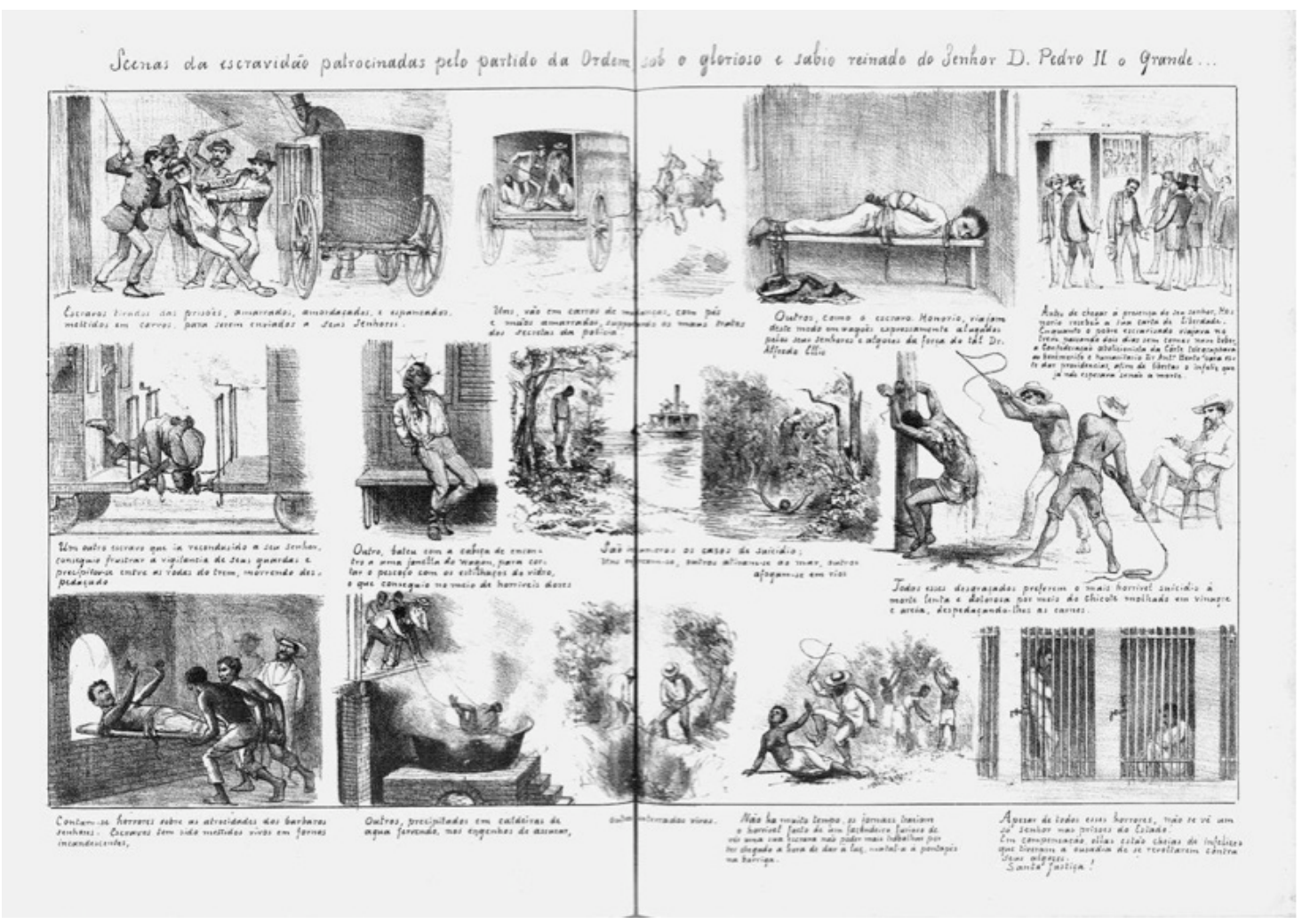

\footnotetext{
${ }^{24}$ Sobre os capoeiras ver, entre outros: SOARES, Carlos Eugênio Líbano. A negregada instituição: os capoeiras no Rio de Janeiro. Rio de Janeiro: Secretaria Municipal de Cultura/Departamento de Informação Cultural, Divisão de Editoração, 1994 e TALMON-CHVAICER, Maya. The hidden history of capoeira: a collision of cultures in the brazilian battle dance. Austin: University of Texas Press, 2008.
} 
Temos aqui mais uma crônica ilustrada. Cada quadro serve para compor um verdadeiro desfile de horrores. Mistura cenas de crueldade explícita com outras de desespero extremo, que teriam levado alguns escravos ao suicídio. O título da crônica chama a atenção: "Cenas da escravidão patrocinadas pelo partido da Ordem, sob o glorioso e sábio reinado do Senhor Pedro II o grande..." O interlocutor aqui é o imperador, cujo reinado é ironizado, e o partido da Ordem, ou seja, o partido Conservador, entáo presidido por João Maurício Wanderley, o barão de Cotegipe. O que é mostrado são consequências da escravidão, sendo os escravos as maiores vítimas.

Os pressupostos das cenas que compóem essas histórias de crueldade interessam ser analisados. As situaçôes descritas são, todas elas, supostamente denúncias de atrocidades reais cometidas contra escravos por senhores bárbaros com a anuência, em muitos casos, do governo. Um teria sido queimado vivo, enquanto uma mulher grávida é espancada até a morte por não conseguir mais trabalhar por força de sua condição. Em um deles é jogada água fervendo, enquanto outro é retirado da prisão e espancado para ser devolvido ao senhor. Há, até mesmo, a história do escravo Honório, uma pessoa real, com nome, que teria sofrido com uma viagem longa, estando amarrado e amordaçado, sem receber água, nem comida. Graças à ação pronta e determinada da Confederação Abolicionista da Corte, com o auxílio do abolicionista paulista Antônio Bento - numa sugestão de que haveria uma relação de colaboração direta entre os diversos grupos de abolicionistas —, teria recebido sua carta de alforria. Alguns sáo escravos torturados por outros escravos para o deleite de senhores que presenciam, supostamente com prazer, as cenas. Sem apresentar justificativa, seriam realizadas somente para aplacar a sede de sangue dos senhores. Cenas de completa barbárie, que mostrariam a incivilidade dos senhores. Efeitos da escravidão, instituição que contaminaria a tudo e a todos.

Os outros escravos são tomados pelo desespero e por isso atentam contra a própria vida. Amarrados ou não, esses escravos preferem uma morte dolorosa à morte lenta da escravidão, como fica bem explícito na legenda: "Todos esses desgraçados preferem o mais horrivel suicídio à morte lenta e dolorosa por meio do chicote molhado em vinagre e areia, despedaçando-lhe as carnes." Junto a cenas orientadas para exprimir horror, destinadas a comover os leitores, o texto complementa o sentido com palavras muito bem escolhidas, marcadas por um eloquente tom de denúncia humanitária. A estampa indica haver apenas dois caminhos possíveis aos escravos: a morte voluntária, e não menos dolorosa, ou a morte lenta e cruel promovida pelos senhores. De certo modo, cada quadro carrega uma mensagem: náo haveria caminho humano dentro da escravidão.

Novamente, os detalhes da construção de cada parte dessa peculiar história contada em quadros merecem destaque. Todos os escravos mostrados são muito parecidos. Não há matizes de cores, tampouco traços fisionômicos distintivos: são quase todos homens. Nada diferencia os personagens. Cada um é, de forma indistinta, vítima da violência senhorial e do Estado. Quanto aos trajes, apenas uma calça, branca ou riscada, com ou sem camisa. Exceção apenas 
aos escravos fugidos, que usam chapéu e paletó, referência à possível estratégia para dissimular sua condição. Todos com expressão de dor ou pavor, todos indefesos. Mas, ainda assim, cada um reage às atrocidades sofridas. Eles sáo descritos, portanto, como pessoas, como parte da humanidade, ainda que uma parte menos desenvolvida dela. Por isso o sofrimento dos cativos deveria ser levado em conta e constituir parte dos argumentos em favor da abolição. Cruzando com outras fontes, não é difícil perceber os elementos que constroem esses personagens.

Os escravos presos na Casa de Detenção do Rio de Janeiro entre 1860 e 1880 têm perfis muito variados. Além de ofício definido, cores diversas - pretos, mulatos, pardos, cabras, fulos - , usavam roupas variadas. Dos 8.446 casos registrados, 2.698 entraram como escravos. Desses, há detentos de muitas nacionalidades. Um número considerável de cativos procurava a polícia por iniciativa própria, muito embora fossem percentualmente poucos em relação àqueles presos por fuga, suspeita de fuga, suspeita de serem escravos ou por ordem senhorial. No quesito roupas, é possível encontrar algumas que se enquadram com perfeição no modelo dos desenhos, junto com uma diversidade enorme de modelos que não correspondem às imagens da imprensa ilustrada. Temos escravos com e sem chapéu, podendo este ser de palha ou de lebre, com calças de algodão, ganga azul, riscadinho, casimira, brim, preta, branca, com e sem paletó, que podia ser de chita ou brim, camisas de chita, algodão, flanela, de cores e modelos diversos. O mesmo se verifica para as mulheres, que usam saias, vestidos, calças e camisolas de tecidos e cores variadas, além de chalés, paletós, todos com as mais diversas possibilidades de combinação. Não parece, observando esse verdadeiro desfile de moda, que a princípio a roupa fosse um elemento que permitisse fácil identificação da condição de quem quer que fosse.

As fichas da Casa de Detenção apontam, assim, para um elemento ausente nas imagens: além de muito dessemelhantes fisicamente, os não brancos de uma forma geral, e os escravos de modo particular, estavam bem distantes da imagem de impotência construída por Agostini. A Revista, desta feita, operava com tipos muito bem delimitados. Não estamos diante nem de cenas tampouco de pessoas reais, mas do escravo vadio e vitimizado, do capoeira violento e irracional, em suma, de estereótipos cuidadosamente construídos. São personagens dessa imprensa, são caricaturas. Há um esforço para construir modelos que revelam tipos com características muito bem delimitadas. A principal diferença: um ameaça a tranquilidade pública, era um perigo a ser vigiado de perto e combatido, os outros são vítimas passivas dos horrores da escravidão e vadios em potencial. Ambos seriam fruto da escravidão e da raça e eram faces de uma mesma moeda.

Portanto, se estavam submetidos a violências extremas, como denunciam os quadros da Figura 4, o resultado dessa violência poderia ser tudo, menos os definidos por Agostini. E é bastante razoável imaginar que Agostini, e decerto outros abolicionistas, tivesse percepçóes bem claras disso. Assim sendo, minha tese é a de que Agostini construía argumentos políticos por meio de suas estampas de personagens negros. Ele criava tipos relativamente simples, 
“Transiçẫo de cor": RaÇa e aboliçấo nas estampas de negros de Angelo Agostini na Revista Illustrada

definíveis por atributos naturais — a raça — e sociais — a escravidão. Nesse movimento, apagava grande parte das características e da diversidade dos sujeitos escravizados, bem como dos libertos e livres de cor. Estes eram sujeitos táo mais dessemelhantes e complexos do que os estereotipados delineados pelo artista do lápis. Ao mesmo tempo, o argumento do medo - fosse ele da violência dos capoeiras ou da vadiagem potencial dos futuros ex-escravos - nos informa que as ações de escravos, libertos e livres não brancos faziam parte do cálculo político de Agostini. Por isso ele, assim como abolicionistas como Joaquim Nabuco, se empenhavam em produzir imagens unívocas desses sujeitos de modo a anular a possibilidade de interferência deles no processo que levaria ao fim da odiada instituição. Afinal, um dos elos, ou elementos comuns dessas imagens da Revista Illustrada, era a incapacidade de ação ordenada e ordeira dos personagens negros aliada aos perigos que eles representavam. Os desenhos expressam uma visão racializada, que oscila entre a vadiagem, a violência despropositada ou a incapacidade de ação. Parece haver, por paradoxal que possa soar, um esforço para retirar de cena os sujeitos escravizados. A ênfase se voltava para a denúncia da violência e dos males da escravidáo para os cativos e para o país. Tal ênfase buscava atribuir um sentido humano à questão e assim conquistar adeptos para a causa da abolição, cujos desdobramentos eram ainda incertos na década de 1880 .

Nos meses finais da escravidão, uma imagem sintetiza muitos dos elementos aqui trabalhados.

Figura 5 - Revista Illustrada, n. 471, p. 5, 19 nov. $1887^{25}$

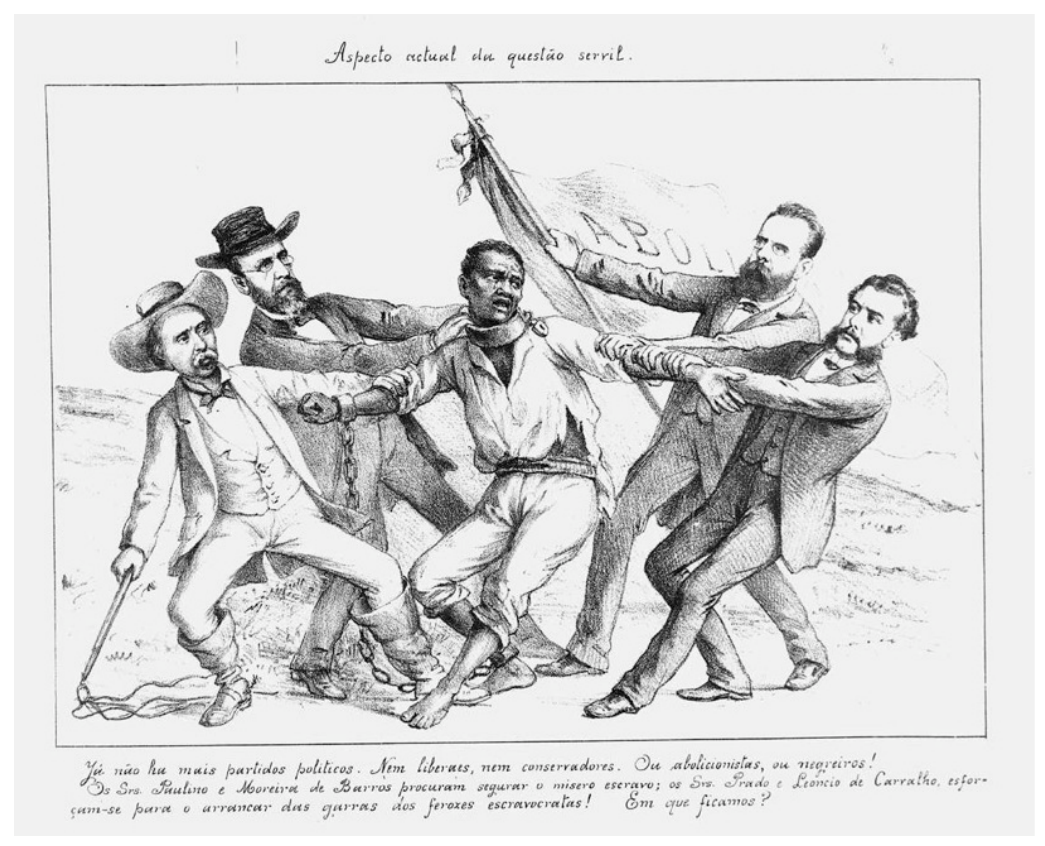

\footnotetext{
${ }^{25}$ A data deste número 471 está claramente errada. A edição anterior é de 5 de novembro de 1887 e a que a seguiu data de 12 de novembro de 1887.
} 
“Transiçấo de cor”: RaÇA E aboliçấo nas estampas de negros de Angelo Agostini na Revista Illlustrada

Disputado por escravocratas e abolicionistas, a quem dirige um olhar que mistura medo e súplica, descalço e usando roupas brancas, este personagem é a própria imagem da incapacidade. Sua esperança está voltada para os abolicionistas, de cuja ação seria dependente. Nessa espécie de cabo de guerra, o escravo é a corda. Bem verdade que não é uma corda qualquer, pois sua feição de súplica e o esforço que faz para pender para o lado abolicionista são expressão inequívoca de sua vontade. Ao final, parece que os esforços de Angelo Agostini e de seus colegas abolicionistas lograram êxito: ao mesmo tempo que contribuíram para a extinção da escravidão, produziram a imagem do ente incapaz, vadio, perigoso, desfigurado e oprimido que deveria ser cuidado, guiado e instruído, por não ser considerado pronto para dirigir seu próprio destino.

\section{Fontes e referências bibliográficas}

\section{Fontes}

AZEVEDO, Aloisio. O cortiço. Rio de Janeiro: Garnier, 1890, p. 108. Disponível em: $<$ http://www.brasiliana.usp.br/bbd/handle/1918/00227900\#page/9/mode/1up>. Acesso em: 9 jan. 2015.

Banco Casa de Detenção do Rio de Janeiro, Cecult, Unicamp.

Careta, Rio de Janeiro, 1910.

Gazeta de Noticias, Rio de Janeiro, 1887.

O Paiz, Rio de Janeiro, 1888 e 1910.

Revista Illustrada, Rio de Janeiro, 1878-1888.

\section{Bibliografia}

ALBUQUERQUE, Wlamyra R. de. O jogo da dissimulação: abolição e cidadania negra no Brasil. Sáo Paulo: Companhia das Letras, 2009.

AZEVEDO, Celia Maria Marinho de. Onda negra, medo branco: o negro no imaginário das elites — século XIX. 3. ed. São Paulo: Annablume, 2004.

AZEVEDO, Elciene. $O$ direito dos escravos: lutas jurídicas e abolicionismo na província de São Paulo. Campinas: Editora da Unicamp, 2010.

BALABAN, Marcelo. Poeta do lápis: sátira e política na trajetória de Angelo Agostini no Brasil imperial. Campinas: Editora da Unicamp, 2009. 
“Transiçẫo de cor": RaÇa e aboliçấo nas estampas de negros de Angelo Agostini na Revista Illustrada

BETHELL, Leslie; CARVALHO, José Murilo de (Orgs.). Joaquim Nabuco e os abolicionistas britânicos: correspondência 1880-905. Rio de Janeiro: Topbooks, 2008.

CARVALHO, José Murilo de. Congresso Agricola - edição fac-similar dos anais do Congresso Agrícola, realizado no Rio de Janeiro em 1878. Rio de Janeiro: Fundaçáo Casa de Rui Barbosa, 1988.

CHALHOUB, Sidney. Solidariedade e liberdade: sociedades beneficentes de negros e negras no Rio de Janeiro na segunda metade do século XIX. In: CUNHA, Olívia Maria Gomes da; GOMES, Flávio dos Santos (Ogs.). Quase cidadão: histórias e antropologias da pósemancipação no Brasil. Rio de Janeiro: FGV Editora, 2007.

CHALHOUB, Sidney. A força da escravidão: ilegalidade e costume no Brasil oitocentista. São Paulo: Companhia das Letras, 2012.

CONRAD, Joseph. Os últimos anos da escravatura no Brasil - 1850-1888. Rio de Janeiro: Civilização Brasileira, 1975.

CORREA, Mariza. As ilusóes da liberdade: a Escola Nina Rodrigues e a antropologia no Brasil. 2. ed. rev. Bragança Paulista: Edusf, 2001.

COSTA, Emilia Viotti da. A abolição. São Paulo: Editora Unesp, 2008.

KERR, David S. Caricature and French political culture, 1830-1848: Charles Philipon and the illustrated press. Oxford: Clarendon Press; Nova York: Oxford University Press, 2000.

KNAUSS, Paulo; MALTA, Marize; OLIVEIRA, Cláudia de; VELOSO, Mônica Pimenta (Orgs.). Revistas Ilustradas: modos de ler e ver no segundo reinado. Rio de Janeiro: Mauad, 2011.

LIMA, Herman. História da Caricatura no Brasil. Rio de Janeiro: José Olympio, 1963.

LUSTOSA, Isabel (Org.). Imprensa, humor e caricatura: a questão dos estereótipos. Belo Horizonte: Editora da UFMG, 2011.

LUSTOSA, Isabel (Org.). Agostini. Obra, paixão e arte do italiano que desenhou o Brasil (1843-1910). Rio de Janeiro: Casa de Ruy Barbosa, coleção FCRB Estudos, v. 15, 2014.

MACHADO, Maria Helena P. T. O plano e o pânico: os movimentos sociais na década da abolição. São Paulo: Editora da UFRJ/Edusp,1994.

MARINGONI, Gilbeto. Angelo Agostini - a imprensa ilustrada da corte à capital federal, 1864-1910. 1. ed. São Paulo: Devir Livraria, 2011.

MARTIN, Michèle. Images at war: Illustrated Periodicals and Constructed Nations. Toronto: University of Toronto Press, 2006.

MATTOS, Hebe Maria. Das cores do silêncio — significados da liberdade no sudoeste escravista. Brasil. Século XIX. Rio de Janeiro: Nova Fronteira, 1998.

REDIKER, Marcus. O navio negreiro: uma história humana. São Paulo: Companhia das Letras, 2011. 
ROCHA, Antonio Penalves. Abolicionistas brasileiros e ingleses: a coligação entre Joaquim Nabuco e a British and Foreing Anti-Slavery Society (1880-1902). São Paulo: Editora Unesp/Santana do Parnaíba; São Paulo: BBS Treinamento e Consultoria em Finanças, 2009. SCHWARCZ, Lilia Moritz. O espetáculo das raças: cientistas, instituiçóes e questão racial no Brasil - 1870-1930. São Paulo: Companhia das Letras, 1993.

SKIDMORE, Thomas E. Preto no branco — raça e nacionalidade no pensamento brasileiro. São Paulo: Companhia das Letras: 2012.

SLENES, Robert W. Na senzala, uma flor - esperanças e recordaçôes na formação da família escrava - Brasil Sudoeste, século XIX. Campinas: Editora da Unicamp, 2011.

SOARES, Carlos Eugênio Líbano. A negregada instituição: os capoeiras no Rio de Janeiro. Rio de Janeiro: Secretaria Municipal de Cultura/Departamento de Informação Cultural, Divisão de Editoração, 1994.

TALMON-CHVAICER, Maya. The hidden history of capoeira: a collision of cultures in the brazilian battle dance. Austin: University of Texas Press, 2008. 